\title{
Religious Leaders and Elections in the Polarizing Context of Indonesia
}

\author{
M. Iqbal Ahnaf'; Danielle N. Lussier ${ }^{2}$ \\ ${ }^{1}$ Center for Religious and Cross-cultural Studies, Universitas Gadjah Mada, Indonesia \\ ${ }^{2}$ Department of Political Science, Grinnell College, USA \\ Corresponding Author: iqbal.ahnaf@ugm.ac.id
}

\begin{abstract}
Studies of elections in young democracies point to the risk of elections intensifying existing social conflicts, a process observed in Indonesia in recent years. The 2017 mayoral election in Yogyakarta contradicts this trend, presenting an empirical puzzle. Despite the fact that local conditions might encourage electoral mobilization along sectarian lines, we find evidence of restraint. Based on analysis of the contents of sermons in 12 mosques and churches in the month before the election we identify three factors that discourage religious leaders from exercising opportunities to intensify religious tension. These include (a) elites were not motivated to exacerbate communal tension because they do not feel the election will bring about reform or change that would seriously affect their established position, (b) even though sectarian messaging is possible, the elites did not believe masses could be easily persuaded by sectarian political messaging, and (c) political outbidding by using sectarian messages would risk confronting the local dominant culture of harmony. These findings suggest that several factors need to be activated for religious leaders to exercise their moral authority over worshippers for political purposes. The presence of an opportunity structure for intensifying sectarian conflict is not sufficient for that conflict to emerge.
\end{abstract}

Keywords: election; violence; religion; tolerance; sermon

\section{INTRODUCTION}

Studies of democracy in plural societies show the risk of elections in intensifying existing social conflict. A number of analysts believe that countries that have only recently undergone democratization are especially vulnerable to electoral violence because political institutions and society's commitment to democratic procedures and outcomes are still weak (Mansfield and Snyder 1995; Snyder 2000). Others contend that the threat of elections exacerbating nationalist chauvinism and ethnic conflict is not exclusive to democratizing states, but also applies to developed states with longstanding democratic regimes. The recent work of Amy Chua coined the word "political tribes" to denote the persistence of communal fragmentation based on racial identity (Chua 2018). She argues that ethnic and tribal identity plays a more powerful role in national politics than has been previously acknowledged. From disenfranchised African Americans in the United States, anti-Chinese sentiment in Vietnam to the Shiite-Sunni divide in Iraq, Chua calls for foreign policy makers to acknowledge the reality that humans are tribal and therefore they cannot be persuaded by modern rhetoric, such as democracy versus authoritarianism or the free world versus "the axis of evil." In a context of political tribalism, democracy may serve to inflame intra-national differences if democratic states are unable to discover a national identity that transcends political tribes (Chua 2018).

Certainly these alarmist perspectives are not meant to discount democratization as an ideal, but they offer a reminder on the need to work on strengthening the conditions required for making democracy work. This may hold true in many examples of countries in which democratic institutions are fairly young or are 
particularly vulnerable to elite manipulation. However it should be noted that such a skepticism tends to neglect the fact that elections in young democracies have been more frequently peaceful than violent. Indonesia, which in 2018 celebrated 20 years of departure from the authoritarian regime of Soeharto, is a valuable case for examination. While the high profile presidential election of 2014 and Jakarta gubernatorial election of 2017 demonstrated that political competition can take the shape of sectarian struggle in the world's largest Muslim-majority democracy, significantly less attention has been paid to elections where such conflict is absent The particular role of religious leaders as agents who can deploy their moral authority among worshippers to either promote or defuse political tribalism has not been fully scrutinized. Under what conditions are religious leaders likely to exercise their moral authority among worshippers to encourage political mobilization?

In order to address this question, we analyze the sermons delivered in 12 houses of worship (mosques and churches) in the four weeks before the 2017 mayoral election in Yogyakarta, Indonesia. While many of the conditions that Snyder (2000) identifies as likely for elections to exacerbate existing communal conflict are present in this particular election, we find that conflict did not escalate. Consequently, this particular election provides us with a valuable case study for understanding why actors exercised restraint. Following Snyder (2000) and Mansfield and Snyder (2007), we suggest at least three factors discourage religious leaders, who may act in accordance with political cues, from exercising opportunities to intensify religious tension. These include: (a) political elites were not motivated to exacerbate communal tension because they do not feel the election will bring about reform or change that would seriously affect their established position, (b) even though sectarian messaging is possible, the elites did not believe masses could be easily persuaded by sectarian political messaging, and (c) even though the political contest is close and it is possible to identify candidates with sectarian sentiment, political outbidding by using sectarian messages would risk unsettling an overall power balance.

\section{ELECTIONS AND INTENSIFICATION OF COMMUNAL TENSION}

The concern that elections in democratizing states could intensify existing tension appears in many writings, such as Cederman, Hug, and Krebs (2010), Gleditsch (2002), Mansfield and Snyder (2007), Collier (2009), Dunning (2011), and Mann (2003). Ideally, electoral politics could substitute for armed conflict as a way to channel political aspiration and social grievances. However, the nature of the relationship between elections and violence is not always substitutionary, but complementary. Political actors may not always choose to submit their fate to the ballot box, but attempt to influence the result in the ballot box by force. In the electoral process, they may intensify conflict and incite violence when they believe that escalation would help raise their popularity and ultimately win at the ballot box.

In an era of "tribal nationalism" (Arendt 1994), religion and other primordial identities may play a central role in electoral politics. Elections risk the intensification of latent conflict between groups associated with religion and tribal identities. The risk is bigger in democratizing countries with plural and divided societies (Horowitz 2006; Lijhpart 1977, Reilly and Reynolds 1999). In a country in which electoral systems are not engineered to reduce the political salience of ethnic, racial, religious, or linguistic identities, it is often easier for politicians to attract support by appealing to ethnic and religious sentiments than class and ideology. Hence elections could bring about the opposite of the ideal result, a peaceful resolution of conflict, instead becoming "dangerous places," to use Collier's words (2009), for escalating communal conflicts. Younger democracies like Indonesia are of particular concern because these states are ethnically diverse and have shorter histories of genuine political competition. Many segments of the population are still resistant to the underlying liberalism of democracy; elites left over from the old authoritarian regime remain politically active, and democratic institutions do not have deep roots. Under such conditions, the survival of democracy may face difficult challenges to develop and could even be exploited to serve an illiberal agenda (Zakaria 1997; Lussier 2016) where minority rights are threatened. Indeed, Freedom House's Freedom in the World report marks Indonesia as "partly free" primarily because of the country's challenges with discrimination and violence against minority groups and "the politicized use of defamation and blasphemy laws."

The risk of conflict escalation does not necessarily emerge from pre-existing conflicts in a plural society. Society may already have traditional mechanisms for resolving conflict. What is most dangerous, according to Snyder (2000), is the choice of political actors contesting in elections, not pre-democratic rivalries. According to Snyder, at least four conditions may encourage elites to attract voters by using hateful sectarian sentiment.

First, in what Snyder calls the condition of "elite persuasion," an election in a democratizing society is 
likely to exacerbate existing conflict when elites feel that they are threatened by the arrival of democracy. Elites may choose to mobilize along sectarian sentiments in nationalism, religion, or ethnicity when they see that an electoral loss could risk serious threat in a rearranged power structure. By invoking nationalism, elites can make an argument for cultural distinctiveness that protects their political interests while challenging the claims of rivals. This approach can be employed both by existing power holders, or by their rising political opponents. As Snyder suggests, nationalism can be wielded effectively by a rising group "who use it as a populist club that can be wielded against elites who are insufficiently zealous in promoting the interest of "the nation"" $(2000,10)$.

Second, elites' choice to exacerbate communal tension is also shaped by calculations about how easy it is for them to persuade the masses using sectarian rhetoric. This condition will depend on the existing cleavages in society. Sectarian polarization in society will be perceived by elites as an opportunity to play the sectarian card. The possibility of supplying information might also provide an opportunity for persuading the masses. In young democracies, the legal framework for the media and journalism may be weak and thus serves as a favorable condition to find channels to supply hateful sectarian messages (Snyder 2000).

Third, an incomplete transition from autocracy toward democracy is fraught with the danger of violent conflict in states where political institutions are weak. When the government, police, and security institutions are insufficient authorities or are vulnerable to corruption, elites may ally with vigilante groups to intimidate opposition and wage "war" based on communal sentiment because they believe that their violent intimidation would be unlikely to provoke legal consequences.

Fourth, elites may see an incentive in using sectarian rhetoric as a political outbidding strategy when the contest is close and political competitors need a bigger arsenal to outbid their opponents. In this situation it is always possible to find ethnic and religious differentiation to attack opponents. This is easier when the contest is between two opposing rivals, but it is also not impossible for religious outbidding to occur when more than two parties are contesting. According to Rabushka and Shepsle (1972), sectarian political outbidding is attractive when competing parties offer similar behaviors or programs. Parties may be exhausted by contesting along programmatic lines because they believe such rational rhetoric will play a minor role in vote choice. In this situation, elites may perceive that playing the ethnic card may make a difference.
These four conditions for escalating communal tensions during an election may not all be available. However, the availability of one condition may depend on the availability of other conditions. As we later explain, these different conditions are helpful in explaining why escalation of communal tension did not occur during the 2017 mayoral election in Yogyakarta.

\section{ELECTIONS AND COMMUNAL TENSION IN INDONESIA}

In the early years of democratization from 1998-2000, Indonesia suffered a number of large scale events of communal violence and civil wars. In 1998, the process toward transition was mired with bloody riots against Chinese across the nation. This was followed with Muslim-Christian civil wars in Maluku and Dayak ethnic cleansing against Madurese in West Kalimantan in 19902000 (van Klinken 2007). After this transitional period, the democratization process stabilized and large scale communal violence no longer occurred. Aside from small incidents of violence, elections have been largely free of large scale communal violence. In the early 2000s the country deepened democratization by reforming the electoral system to promote direct elections for a number of offices. In 2004 Indonesia issued a new law on regional autonomy that included the introduction of direct election of regional and district executives. Previously, regional leaders (from provincial to district and city level) were elected indirectly by members of regional Houses of Representatives. This reform brought political contestation much closer to the people and thus increased the risk of elections' damaging social cohesion. Because Indonesia is a large country with more than 500 hundred districts and cities, the law dramatically expanded the role of elections in Indonesians' lives and proved challenging to implement. It took more than ten years before regional elections could be held simultaneously across regions. Because the terms of previous regional officers were not the same, regional elections happen every year in different regions. These elections are in addition to the many village-level elections that happen more frequently and even closer to the people.

The record of regional elections with regard to incidents of violence is equivocal. On one side, regional elections have been largely peaceful. The Indonesia Science Institute (Lembaga Ilmu Pengetahuan Indonesia/ LIPI) recorded that violence only occurred in 3 percent of all elections in 2005-2008 (Nurhasim 2009). The International Crisis Group recorded only 20 incidents of violence out of 220 elections in the year 2010, or in 
approximately 9 percent of elections (International Crisis Groups 2010).

Yet, even though incidents of violence remain low, regional elections have not been entirely peaceful. The use of identity politics, which often polarize society based on sectarian lines, is prevalent. As Fox and Menchik (2011) have noted, the majority of campaign posters in 2009-2011 emphasized the association of candidates with symbols of religious and ethnic identities (Fox and Menchik 2011). Campaigning along the lines of one's identity may not result in an outbreak of violence, but such politicization of identity may damage social cohesion and civic culture. In post-conflict and divided regions like Maluku, West Kalimantan, Central Kalimantan, and Central Sulawesi, peaceful elections were only possible if pairs of candidates followed power-sharing norms between dominant religious or ethnic groups. In these regions, if a candidate for governor is Muslim, the candidate for vice governor must be Christian (Tomsa 2009; Brown and Diprose 2007). This norm resembles Lijphart's "consociational democracy" model (Lijphart 1969), and while it is not a formal written policy, it was commonly seen as a requirement to ensure that elections would run peacefully.

In many cases local elections often intensified existing intolerance and persecution against minority groups. Ahnaf, Maarif, Asyhari, and Afdillah (2014), for example, show how elections provide a political opportunity structure that results in the accumulation of power and resources in the political alliance that rallied on intolerant sentiment against weak targets of religious minorities. As political actors allied with parties in communal tension, winners resorted to hateful rhetoric, and sometimes promised that, if elected, they would limit the rights of and even expel the minority group. For example, in the 2012 district election in Sampang, East Java, the incumbent district head, Noer Tjahja, allied with prominent anti-Shiite clerics in the district (Ahnaf et al. 2015). The election coincided with the rise of anti-Shiite movement in many places in Indonesia including Sampang. While many politicians adopted anti-Shite rhetoric, Noer Tajahja was infamous for his speech in which he promised that if reelected, he would make Shiite leave Sampang within three months. This hateful approach was not successful and Noer Tjahja was not reelected. In several instances, deadly violence and persecution against minority groups broke out in the months before an election.

The concern that elections are damaging to Indonesia's civic culture by exacerbating social tensions is most notable in the case of the 2014 presidential election. In the 2014 presidential election, two pairs of candidates contested, Prabowo-Hatta Rajasa vs. Joko Widodo-Jusuf Kalla. The first pair, Prabowo-Hatta was supported by a coalition that included a pool of Islamist parties and hardline Islamist organizations. As Joko Widodo-Jusuf Kalla were mainly nominated by a nationalist party, historical hostility between Islamist and nationalist segments of society were exacerbated. Consequently, the election was mired with hateful rhetoric accusing Joko Widodo of being the son of a Communist, a Christian allying with the foreign power of atheist China and thus representing an infidel power against Islam. Despite the fact the both Joko Widodo and Jusuf Kalla are pious Muslims, the hateful rhetoric was normalized and sustained by a narrative emphasizing the return of Communism and Christian domination. This polarizing election turned hardline intolerant groups into prominent political actors.

The sectarian rhetoric was not enough to bring victory to Prabowo-Hatta, but it succeeded in entrenching continued polarization in society based on religious and sectarian issues. Hardline groups have strengthened their position in society and maintained their political relevance. This sustained sectarianism bore fruit in the 2017 Jakarta gubernatorial election when a coalition led by a party in opposition to the presidential administration (Gerindra) again relied on the support of hardline groups to defeat the candidate supported by a coalition led by the ruling party, the Indonesian Democratic Party of Struggle (PDIP). The opposition rallied on the accusation of incumbent governor Basuki Tjahaja Purnama (more commonly referred to as Ahok), the gubernatorial candidate supported by the ruling party coalition, as blasphemous against Islam. The fact that Ahok is a double minority (Chinese and Christian) made it easier for the opposition party to mobilize the electorate using religious and racial sentiment. According to a report by the Institute for Policy Analysis of Conflict in Jakarta, influential ulama had decided already in 2015 to use Friday sermons to communicate to Muslims that they are obliged to vote for Muslim leaders. This approach was realized in late 2016 and early 2017 as mosques became mobilization centres deploying conservative and hardline religious figures to attack Ahok and his supporters as enemies of Islam.

This tactic helped the opposition win the 2017 gubernatorial election in Jakarta, and it inspired political actors in other regions to adopt similar tactics. Hardline Islamist groups tried to follow alliance with the opposition party in other regional elections and thus sustained the intensification of communal tension beyond Jakarta. 
The above cases of elections with the potential to turn violent highlight the important role of religious leaders and houses of worship in electoral mobilization that could exacerbate communal conflict. As the 2014 Indonesian presidential election and the 2017 Jakarta gubernatorial election demonstrate, when political actors and religious leaders found shared interests, they did not hesitate to use mosques and religious sermons to connect political competition in elections to religious issues and sentiments. However, the 2017 mayoral election in Yogyakarta baulks this trend. Despite the fact that conditions, in terms of the timing of the election and the candidates' support bases, might encourage political actors to mobilize the electorate along sectarian lines, we found that political messaging in houses of worship during the election in Yogyakarta was largely oblique. There is almost no association between the electoral contest and religious competition in the messages delivered. Even in those houses of worship that are located in the support bases of rival political parties, political messaging was mostly peaceful. The sermons in houses of worship were not free from political messaging. However, the fact that religious leaders restrained from jumping into the arena of political competition to intensify communal tension is unexpected given the fact that local and national conditions might motivate them to do so. This restraint is in line with the campaign messages of the candidates and their supporters, which did not appear sectarian.

\section{MAYORAL ELECTION IN YOGYAKARTA: POTENTIAL FOR CONFLICT ESCALATION}

The mayoral election in Yogyakarta held in February 2017 was a contest between two former political allies. Incumbent mayor, Haryadi Sujudi was challenged by his vice mayor, Imam Priyono. In this election, Haryadi Sujudi and his running mate Heroe Purwadi were nominated by a coalition of parties, including three opposition parties at the national level, the Great Indonesia Movement Party (Gerindra), the Prosperous Justice Party (PKS), and the Democrat Party. Imam ran with Achmad Fadli, supported by a coalition led by ruling party PDIP. Haryadi-Heroe Purwadi won the election with slight margin of 1,187 votes out of about 200,000 total votes (Tempo 2017) (See Table 1). The election was peaceful and even though the victory margin was very close, legal channels were used to challenge and resolve all disputes, ultimately declaring Haryadi the winner two months after the election. Yogyakarta holds the status of special province, which confers to it a particular relationship with the national government. Because of the region's unique contribution during Indonesia's war for independence, Yogyakarta has been allowed to fuse the traditional authority of a Sultanate with state authority. Instead of being elected, the governor and vice governor follow the heredity tradition of the JavaneseIslamic kingdom of Mataram. The Sultan of Mataram and the head of its affiliated regional authority of Pakualam palace were granted the exclusive right of positions as governor and vice governor. Hence direct elections for executives in Yogyakarta only happen at the lower levels of the district, municipality and villages. At this lower level of election, the contests have been mostly peaceful.

Table 1. Result of 2017 Mayoral Election, Yogyakarta

\begin{tabular}{|c|l|l|}
\hline No & Candidates, Supporting Parties & Votes \\
\hline \multirow{2}{*}{1} & Imam Priyono-Achmad Fadli & $49.70 \%$ \\
& Parties: Golkar, Gerindra, PKS, & 99,143 votes \\
\cline { 2 - 3 } 2 & PAN, Demokrat & \\
\hline \multirow{2}{*}{2} & Haryadi Sujudi-Heroe Poerwadi & $50,30 \%$ \\
& Parties: PDIP, PKB, Nasdem & 100,332 votes \\
\hline
\end{tabular}

However, Yogyakarta's peaceful image has changed in the last five years. Various independent human right observers have noted that Yogyakarta is shifting from the "city of tolerance" to a "city of intolerance." This verdict is based on data documenting an increase in incidents of violence against minority groups and restrictions on academic freedom. Yogyakarta is the second region with the highest number of intolerancenuanced violence in 2014 (Wahid Institute 2014; Setara Institute 2014). According to Ahnaf and Salim's report (2017), the incidents of violence in the region have drastically increased since 2014. In this period, vigilantism was quite routine, targeting minority groups, such as alleged illegal churches, public church events, non-mainstream Muslim groups like the Shiite and Ahmadis, LGBT communities, and human rights and academic forums accused of propagating liberalism and communism. Muslim paramilitary groups who are connected to political elites and rulers in Yogyakarta are believed to be responsible for most of the violence. ${ }^{1)}$

In spite of Yogyakarta's history as a peaceful region, recent increases in violence suggest that an election could create an opportunity for intensifying existing conflict. There are three conditions in Yogyakarta that align with the theoretical considerations offered by Snyder (2000) for when elections escalate social conflict. First, the 2017 mayoral election coincided with a boiling political atmosphere at the national level with mass protests against 
the alleged blasphemous words of incumbent governor of Jakarta, Basuki Tjahaja Purnama (Ahok). Even though Ahok is not a member of any political party, he is closely associated with President Joko Widodo and the ruling PDIP party. Ahok was a former vice governor when Joko Widodo was the governor of Jakarta. He succeeded Joko Widodo when the latter won the Indonesian presidential election in 2014. Ahok became a popular governor with 63 percent satisfaction rate in 2015 (Tempo 2015). He planned to continue his leadership in Jakarta by running in the election in 2017 with support from a coalition led by the ruling PDIP party. The anti-Ahok mobilization started in mid-2016, but gained particular momentum after a September campaign appearance when Ahok made a statement in which he joked that voters should not heed the warnings of the Qur'anic verse al-Ma'idah 51, which warns against taking Jews and Christians as friends. This statement became the basis of the subsequent claim of blasphemy. As the anger grew, a series of antiAhok rallies was organised across Indonesia, including in Yogyakarta. The rallies that demanded the jailing of Ahok peaked on 12 February when more than 500,000 people marched in Jakarta in the so-called 212 Action for Defending Islam. Anti-Ahok protesters attended the rally from different regions. In Yogyakarta groups that were responsible for many acts of anti-minority violence organised busses carrying anti-Ahok supporters to join the rally in Jakarta. Exploited by opposition parties to attack the government, this polarizing discourse on Ahok had the potential to influence political contests at the regional level. The timing is of particular relevance, as the election in Yogyakarta was held in 15 February 2017 , the same day as the first round of the Jakarta election. In short, the Jakarta election had evolved from being a contest over who would rule the capital city to become a more symbolic struggle over the limits of democracy to protect minority rights.

It was this political context that made the antiAhok rally large and politically influential. The public was mobilized to protest against Ahok not only because he allegedly committed blasphemy against Islam, but also because he is Christian and of Chinese descent. Thus, in this period, political discourse was marked by the call to fight the so-called kafir (infidel) leader, boycott political parties that defended blasphemy against Islam, and fight against Chinese domination to be replaced by Muslim and pribumi or inlanders' supremacy (Wildansyah 2018). There was an interest among opposition parties to sustain the political polarization at the local level to challenge the ruling party PDIP and reelection of Joko Widodo in the 2019 general election. In this context of sectarian political divide, it would be easy for political parties, especially the opposition parties, to follow the sectarian rhetoric at the national level and hence intensify existing communal tensions.

Second, the 2017 mayoral election in Yogyakarta brought a face-to-face contest between two pairs of candidates, each endorsed by relatively balanced support bases. The gap of the share of votes between the two candidates is only about 0.7 percent. As Snyder suggests, sectarian rhetoric might be helpful to political actors in the context of close races. In other places, close contests like these tend to encourage the use of identity politics as a political outbidding tactic. This is especially the case when competition is narrowed into two pairs of candidates, which would allow for differentiation in bases of sectarian association. The 2010 mayoral election in Medan, North Sumatera is evidence of this dynamic. The first round of the election was contested by 10 pairs of candidates and every candidate was supported by an interethnic alliance. In the second round of election, the contest was narrowed to two pairs and it was at this stage that religious issues mattered (Aspinall, Dettman and Warburton, 2011)

Third, the two pairs of candidates contesting in the mayoral election in Yogyakarta were supported by coalitions of political parties that followed the pattern of political polarization at the national level. Such a consistent pattern does not always happen in regional elections, as sometimes popular candidates manage to gain support from coalitions that combine the ruling and opposition parties. In Yogyakarta, the incumbent mayor Haryadi Sujudi and his running mate Heroe were supported by a coalition of parties that included Gerindra, PKS, the National Mandate Party (PAN), the United Development Party (PPP), Democrat and Golkar. These parties were the opposition in the 2014 presidential election. Later, three of these parties (Golkar, PAN and PPP) joined the ruling government at the national level, but the leaders of PAN and PPP, especially in Yogyakarta, were very critical of the ruling government. Prominent leaders of PAN, like Amien Rais and his son Hanafi Rais - who both have longstanding local connections to Yogyakarta - accused the ruling government of serving the liberal agenda, favoring foreign labourers over domestic workers, and criminalizing Muslim leaders. As parties with an identity rooted in Islam that advocate for policy programs advancing Islamic values, PAN and PPP in Yogyakarta share a substantial part of the Muslim constituency in the region that joined in the attack against President Joko Widodo. Even when the national leadership of PPP joined the coalition that supports the re-election of Joko Widodo, the Yogyakarta branch of PPP 
opposed the decision and declared a rebellion against the ruling elite of PPP. Golkar is a nationalist inclusive party, but it is known for pragmatism, and regional level leaders have been very open to using sectarian rhetoric or tactics when necessary. This coalition contested against the pair Imam Priyono-Achmad Fadli, who were supported by PDIP and the National Awakening Party (PKB), an Islamic pluralist party.

This composition of factors sets a perfect formula for rallying on sectarian rhetoric, especially because the two political parties that have a history of deep identity rivalry in Yogyakarta, PDIP and PPP (plus PAN) supported different candidates. As Ahnaf and Salim (2017) show, social cleavage in Yogyakarta is marked by the divide between the so called "green" and "red" zones. The green refers to Islamist paramilitary groups connected to PPP's youth wing called the Gerakan Pemuda Kabah (GPK) and the youth wing of the mass modernist Muslim organization Muhammadiyah, Komando Kesiapsiagaan Angkatan Muda Muhammadiyah (KOKAM), which overlaps with the electoral base of PAN. The red zone is associated with a paramilitary group connected to the PDIP party. The paramilitary groups emerged in the early period of transition toward democratization after the fall of Soeharto in 1998. To defend his declining power, Soeharto created vigilante groups to counteract the reform movement, including support to Islamist paramilitary groups like the Islamic Defenders' Front (FPI). After Soeharto fell, many members of the paramilitaries joined youth organizations of political parties. In other places, militant organisations are not always connected to political parties, but in Yogyakarta political parties provide channels that overlap with the major social cleavages of Islamist, nationalist, and traditionalist Muslims.

Yogyakarta's special status and the absence of political competition for top leadership of the province creates an unusual set of incentives for political parties. Rather than competing with each other in order to gain access to the highest political office in the region, they instead compete for social dominance. In doing so, they hope to gain control of public service related businesses and social services, such as schools and hospitals, many of which are under the purview of the hereditary sultanate. To gain access to these spoils, political parties and their paramilitary affiliates need to maintain good relations with the Sultan, which includes restraint from criticizing his development projects and generally maintaining social order.

Vigilante groups have a long history of competition over control of public spaces and the security business sectors in Yogyakarta. Even though members of the groups are multi-religious, issues of identity, nationalist versus Islamist rivalry and competition of Christian versus Islamic institutions (schools and charity organisations) have played a strong role in the rivalry. Violent clashes between groups were not rare. Additionally, the "green" paramilitary groups have displayed a growing interest in showing their muscle by interfering in religious and moral issues. For example, scholars have documented an increase in paramilitary groups' religious repertoires, such as routine religious jihad training for their members and more frequent attacks on religious and social minorities (Ahnaf and Salim 2017).

The mayoral election coincided with the period of this increased sectarian mobilization in Yogyakarta perpetrated by small, but vocal paramilitary groups that supported one of the candidate pairs, Haryadi SujudiHeroe Purwadi. These conditions would favor the use of sectarian rhetoric that might come by supporters of the incumbent mayor. With reference to the issues at the national and local level, sectarian rhetoric may include portrayal of Haryadi-Heroe as representing forces of God (Islam) and the opposing candidates as forces of evil due to their support from parties defending Ahokperceived as a blasphemer of religion, associated with Christian dominating interests, communist ideology and religious heresies. If messages like these were delivered it would be almost certain that the election would intensify existing conflict between the red and green zones and be followed by increased violence or intimidation against minority groups identified as part of the electoral bases of PDIP.

Yet, it is important to recognize that political entrepreneurs are not the only actors with the capability to deliver sectarian political messages. An important facet of escalation along sectarian lines that remains underexplored is the role of religious leaders. While religious identity remains a powerful source of group identity that can be made politically salient by political actors, few individuals look to political leaders as sources of religious inspiration. Rather, it is often the messages delivered by religious authorities in houses of worship that have resonance for individuals seeking to live according to their religious beliefs. When religious leaders affirm the sectarian messages offered by political actors, it increases the likelihood that communal tensions will escalate. Alternately, however, if religious leaders act with restraint and communicate messages of tolerance, this dampens the likelihood that sectarian mobilization will be effective. We find evidence of this effect in Yogyakarta. 


\section{RELIGIOUS LEADERS AND POLITICAL MESSAGING}

As a basis for understanding the political messages delivered by religious leaders, we analyze sermons delivered in eight mosques and four churches in the four weeks prior to the 2017 mayoral election in Yogyakarta. ${ }^{2)}$ We selected a cross-section of mosques and churches that reflect the diversity of the city's religious composition, as well ensuring that neighborhoods with longstanding relationships with specific political parties are included. In total, we examined 47 sermons for political content, finding that 15 included some political information. Of these 15 sermons, 10 mentioned the upcoming elections, three referred to the Ahok controversy, and six included political content unrelated to the elections.

In order to better understand the tone of the messages delivered by religious leaders, we coded each of the sermons along two different dimensions, demonstrated in Table 2. The first dimension measures the level of explicitness of political messages, and is coded so that " 0 " = corresponds to no political message in a sermon; "1" corresponds to a broad political message in a sermon (i.e., the listener does not receive a clear direction for action); and " 2 " corresponds to an explicit political message (the listener receives a clear direction for action). We then aggregated each of these sermons at the level of the house of worship, generating an overall measure of message explicitness for each location. The possible empirical range of this dimension is 0 to 8 .

The second dimension addresses the issue of tolerance or intolerance. Each individual sermon is coded as follows: " 0 " corresponds to the delivery of an intolerant message; " 1 " corresponds to the delivery of a neutral message (including sermons that lacked political content); and " 2 " corresponds to the call for a tolerant message. As with the first dimension, scores

Table 2: Political Messaging in Houses of Worship during 2017 Mayoral Election in Yogyakarta

\begin{tabular}{|c|c|c|c|c|c|}
\hline $\begin{array}{l}\text { Aggregate } \\
\text { scores }\end{array}$ & Explicitness & Consistency & Tolerance & $\begin{array}{l}\text { Alternate } \\
\text { explicitness } \\
\text { measure }\end{array}$ & Aggregate notes \\
\hline Mosque 1 & 3 & 0 & 3 & 1.5 & \\
\hline Mosque 2 & 3 & 1 & 6 & 1 & $\begin{array}{l}\text { Relatively new mosque; has PDIP sign on the wall; } \\
\text { Takmir mentioned to RA that some worshippers had left } \\
\text { this mosque to go to Mosque } 6 \text { as they felt that some of } \\
\text { the preachers were too political in their messages }\end{array}$ \\
\hline Mosque 3 & 3 & 0 & 4 & 1.5 & We only have three sermon observations \\
\hline Mosque 4 & 1 & 1 & 5 & 1 & \\
\hline Mosque 5 & 2 & 0 & 5 & 2 & \\
\hline Mosque 6 & 3 & 0 & 2 & 1.5 & $\begin{array}{l}\text { One very radical sermon; two weeks HTI bulletins with } \\
\text { political info, including discussion of Ahok; and "Jail } \\
\text { Ahok" sticker in wudlu area }\end{array}$ \\
\hline Mosque 7 & 1 & 1 & 4 & 1 & \\
\hline Mosque 8 & 3 & 0 & 4 & 1.5 & \\
\hline $\begin{array}{l}\text { Protestant } \\
\text { Church } 1\end{array}$ & 2 & 0 & 4 & 2 & $\begin{array}{l}\text { Only one sermon mentioned elections; however, } \\
\text { intercessional prayers mentioned them twice; pre-election } \\
\text { workshop, and special letter handed out on Yogya } \\
\text { elections the last week before election }\end{array}$ \\
\hline $\begin{array}{l}\text { Protestant } \\
\text { Church } 2\end{array}$ & 0 & 2 & 4 & 0 & \\
\hline $\begin{array}{l}\text { Catholic } \\
\text { Parish } 1\end{array}$ & 4 & 0 & 6 & 2 & $\begin{array}{l}\text { All four weeks had some mention of the election; twice in } \\
\text { sermon, twice in prayers of the faithful, and } 1 \text { letter in the } \\
\text { mass book from the bishop encouraging voting }\end{array}$ \\
\hline $\begin{array}{l}\text { Catholic } \\
\text { Parish } 2\end{array}$ & 1 & 1 & 4 & 1 & \\
\hline
\end{tabular}

Consistency Code: based on explicitness; 0 = sharply inconsistent; $2=$ consistent

Alternate Explicitness Measure: average explicitness score divided by number of sermons with political content 
for each individual sermon are aggregated to create a score ranging from 0 to 8 for each house of worship. The codes for each specific house of worship are listed in Table 2. Table 2 also provides an alternate score for explicitness across the houses of worship, averaging the level of explicitness across the number of sermons that include political content. The final column in Table 2 adds further details about political messages observed in houses of worship outside of the context of sermons.

On the whole, approximately one-third of the sermons delivered political themes. The highest level of explicitness revealed in the aggregate score is " 4 ," suggesting that most political messages were broad and indirect. For example, a sermon at Mosque 2 focused on the theme of honesty and trust, providing lots of broad references to greed among political leaders and warnings of corruption. Another sermon at this same mosque discussed the compatibility of Islam and nationalism, but refrained from making any specific statements about political parties or actors. Although most of these political messages were oblique or not explicit in terms of advocating for specific candidates, in some instances they may be clear enough for some audience. For example, the more explicit sermons in Mosque 1 and Mosque 8 called on worshippers to vote for Muslim candidates. Another sermon delivered at Mosque 3 cautioned against worshippers voting for individuals to be leaders if they mock religious teachings. In Protestant Church 1, a sermon directed worshippers to reject "money politics," telling them that they should not accept money offered by political candidates and not vote for those who offer it. Explicit sermons in the two Catholic parishes called on worshippers to be smart voters who educate themselves on the election and candidates in order to make good choices. It is worth noting that even these more explicit messages did not necessarily communicate directives that aimed to promote sectarian politics.

With regard to the level of tolerance, in general we see that sermons were generally tolerant, ranging in aggregate scores from 2 to 6 across the 12 houses of worship. In other words, both mosques and churches offered messages that were more tolerant than intolerant. Out 12 houses of worship, intolerant messages only occurred in two cases, Mosque 5 and Mosque 6. And even these rarer intolerant messages refer to tension at the national level, especially the case of the Ahok controversy. No sermon sought to connect the local election with local issues raised in the recent communal tension in Yogyakarta, such as houses of worship and the issue of proselytization, the presence of LGBT communities, "heretic" groups and communist resurgence. Our analysis reveals that rather than inflaming local tensions, preachers in Yogyakarta's mosques and churches frequently delivered tolerant political messages. The sermon in Mosque 2 noted above that discussed the compatibility of Islam and nationalism, for example, emphasized tolerance as central to a shared collective identity and further noted that some individuals - including Muslims who have crossed a violent or radical line - prioritize their own ambitions over the collective good. In another sermon at the same mosque, a preacher from the moderate Nahdlatul Ulama mass organization commented, "Why do we get excited when Ahok or a non-Muslim defames religion? Why do we think nothing at all when a Muslim defames religion?" He continued this logic by noting that individuals who do not offer the five daily prayers have already defamed religion since the daily prayers are a pillar of the religion. A sermon at Mosque 3 emphasized the importance of having good relations with non-Muslims.

The restraint from escalating tension during the election is apparent in the comparison between the level of explicitness and tolerance. As the columns in Table 2 reveal, the level of explicitness is generally higher than the level of intolerance. In other words, political messaging in sermons tends to be tolerant. Religious leaders often spoke about the election and political issues, but they often delivered more tolerant than intolerant messages. The one outlier in our study is Mosque 6, which displayed the lowest tolerance score on our sample (2), while also scoring a 3 on explicitness, which was on the higher side of the empirical range observed. In this particular mosque, two of the four sermons observed included some political content, and both of these messages expressed intolerance. One sermon warned worshippers to be careful of communists and the other specifically named Jews, Christians, communists, LGBT, Shia Muslims, and non-monotheists as infidels. This sermon continued to call on worshippers to not vote for leaders who are "communist, pluralist, Shia and anti-Islam." The preacher also told worshippers that Muslims should not be deceived with issues of tolerance and fundamental rights. In short, all of the political messages received in Mosque 6 were intolerant, although only one offered a specific political directive. Nevertheless, this mosque was exceptional among our sample of 12 houses of worship. On the whole, our research found that even mosques with some explicit political messages tend to deliver peaceful tolerant messages.

For example, while some of the most explicit communication observed in sermons concerned the Ahok controversy, not all comments were openly hostile toward the Jakarta governor. During a sermon at Mosque 
1 , mention of the Ahok controversy was ensconced within a broader discussion of the importance of choosing one's words wisely, with the Jakarta governor alluded to as someone who was not careful in what he said. A sermon at Mosque 5 mentioned the Ahok case, but primarily emphasized leadership qualities such as honesty and trustworthiness, warning against supporting individuals who tried to buy votes. In these examples, but particularly the last, the preacher appeared to problematize a narrative that suggests one's religious affiliation alone is not the most important factor in political leadership. In other words, rather than invoking sectarian identity claims, these sermons suggest a view of the intersection of religion and politics that is more restrained and nuanced.

\section{CONCLUSION}

In contrast to the cases of escalated social tension during elections, our analysis of the 2017 mayoral election in Yogyakarta found that the election did not become a battlefield in the existing communal tension in the province. The 2017 mayoral election took place during a period of intensifying communal tension at the national and local level of Yogyakarta. Increased violence against religious minorities has contributed to heightened tensions in the region. Yet, we show in this article that despite the heated political atmosphere at the national level, religious leaders in Yogyakarta restrained from intensifying sectarian conflict.

This conclusion is based on analysis of sermons in houses of worship during the campaign period. Even though the data is limited to sermons at Friday prayers and Sunday services, it illustrates the general picture of the absence of sectarian mobilization during the election. In many cases of intensifying sectarianism during elections in other regions, religious leaders and houses of worship have played central roles in the mobilization of sectarian campaigns. In these cases, political actors used houses of worship and collaborated with militant preachers to spread hateful sectarian messages to support certain candidates. Therefore, the overall trend of tolerant sermons during the election campaign in Yogyakarta shows the restraint of key actors, religious or political, in jumping into an election to strengthen sectarian polarization.

This finding challenges the hypothesis that polarized and competitive elections increase the likelihood of the exercise of religious and ethnic outbidding by political actors. The 2017 mayoral election in Yogyakarta was both competitive and polarized. Parties with a long history of competition and violence separated candidates. The result of the election was so close that the losing candidate legally challenged the results in court. Yet, sectarian messages were largely absent from the 2017 contest for mayor of Yogyakarta.

The broader political context in Yogyakarta, which prioritizes a culture of harmony and hegemonic rule of the Sultan under the region's special status may explain the lack of mobilized violence during the election. This dominant and hegemonic culture may make sectarianism in political rhetoric counterproductive. For this reason, political actors may have resisted the trend of intensifying violence to conform to the dominant culture.

Yet, our analysis suggests that religious leaders also played a key role in promoting tolerance and resisting the appeal of sectarianism. Sermons delivered in Friday prayers and Sunday services covered primarily religious themes, not political messages. But in the roughly one-third of sermons analyzed that included some political content, messages were generally broad and tolerant. In this instance, religious leaders restrained from escalating existing social tensions. Our analysis suggests the presence of an opportunity structure for intensifying sectarian conflict is not sufficient for that conflict to emerge. Rather, religious leaders can play an important role in facilitating or pushing back against sectarian interpretations of political events. Even when the conditions are present for a sectarian conflict to emerge or escalate, messages delivered in houses of worship have the potential to problematize or challenge a sectarian narrative, contributing to more restrained action.

\section{ENDNOTES}

1) Ahnaf and Salim (2017) show this connection in the political patronage between a prominent Muslim vigilante group, Forum Umat Islam (FUI), and an influential local politician, Syukri Fadholi. With this political connection, the leaders of FUI control community organizations that received government concessions in public affairs, such as parking and security businesses, as well as roles of key tourism activities. FUI uses violence against religious minorities to show its muscle and thus maintain its political influence. See also de Jong and Tiwikromo (2017).

2) Sermon monitoring was carried out by thirteen graduate students from the program for Religious and Cross-Cultural Studies at the University of Gadjah Mada, who were trained in participant observation methodology. These research assistants were trained to write field reports that included a detailed description of the content of sermons at Friday prayers and Sunday worship services. 


\section{REFERENCES}

Ahnaf, M.I., and H. Salim (2017). Krisis Keistimewaan: Kekerasan terhadap Minoritas di Yogyakarta. Center for Religious \& Cross-cultural Studies, Universitas Gadjah Mada.

Ahnaf, Mohammad, Iqbal, Samsul Maarif, Budi AsyhariAfwan, and Muhammad Afdillah (2015). Politik Lokal dan Konflik Keagamaan: Pilkada dan Struktur Kesempatan Politik Konflik Keagamaan di Sampang, Bekasi, dan Kupang. Center for Religious \& Crosscultural Studies, Universitas Gadjah Mada.

Arendt, H. (1994). The Origins of Totalitarianism. New York: Harcourt Inc.

Aspinall, E., S. Dettman, and E. Warburton (2011). "When Religion Trumps Ethnicity: A Regional Election Case Study from Indonesia." South East Asia Research 19(1).

Brown, G., and R. Diprose (2007). Bare-Chested Politics in Central Sulawesi, Indonesia: The Dynamic of Local Elections in a 'Post'-Conflict Region. CRISE Working Paper No. 37.

Cederman, L.E., S. Hug, and L. Krebs (2010). Democratization and civil war. Journal of Peace Research, 47(4), 377-394.

Chua, A. (2018). Political Tribes: Group Instinct and the Fate of Nations. Penguin Press.

Collier, P. (2009). Wars, guns, and votes: Democracy in dangerous places. NewYork, NY: Harper.

Fox, C, and J. Menchik (2011). "The politics of identity in Indonesia: Results from Political Campaign Advertisements." Paper presented at the APSA 2011 Annual Meeting Paper, Seattle, March 31- April 3.

Gleditsch, K. S. (2002). All international politics is local: The diffusion of conflict, integration, and democratization. Ann Arbor: University of Michigan Press.

Institute for Policy Analysis of Conflict (2018). After Ahok: The Islamist Agenda in Indonesia. http://www. understandingconflict.org/en/conflict/read/69/AfterAhok-The-Islamist-Agenda-in-Indonesia

International Crisis Group (2010). "Indonesia: Mencegah Kekerasan dalam Pemilu Kepala Daerah, bias diakses di." http:/www.crisisgroup.org/en/regions/asia/ south-east-asia/indonesia/197-indonesia-preventingviolence-in-local-elections.aspx?alt_lang=id.

Lijphart, A. (1969). Consociational Democracy. World Politics, 21(2): 207-225.

Lijphart, A. (1977). Democracy in Plural Society. Yale University Press.

Lussier, D. (2016). Constraining Elites in Russia and Indonesia: Political Participation and Regime Survival. Cambridge University Press.

Mann, M. (2005). The dark side of democracy explaining ethnic cleansing. New York, NY: Cambridge University Press.

Mansfield, E. D., and J. Snyder (1995). Democratization and war. Foreign Affairs, 74(3): 79-97.

Mansfield, E.D., and J. Snyder (2007). Democratization and civil war. Unpublished manuscript, University of Pennsylvania and Columbia University.

Rabushka, A., and K. A. Shepsle (1972). Politics in plural societies: A theory of democratic instability. Columbus, $\mathrm{OH}$ : Merrill

Setara Institute (2014). Dari Stagnasi Menjemput Harapan Baru: Laporan Kebebasan Beragama/Berkeyakinan di Indonesia Tahun 2014. Jakarta: Setara Institute.

The Wahid Institute (2014). Laporan Akhir Tahun Kebebasan Beragama dan Intoleransi 2014. Jakarta.

van Klinken, G. (2007). Communal Violence and Democratization in Indonesia: Small Town Wars. London and New York, NY: Routledge Contemporary Southeast Asia Series.

Wildansyah, S. (2018). Alumni 212: Yang Koalisi dengan Parpol Propenista Agama Tak Kami Dukung. Detiknews, January 12. https://news.detik.com/ berita/d-3812375/alumni-212-yang-koalisi-denganparpol-propenista-agama-tak-kami-dukung. 